\title{
Impact of socio-sexual conditions on the epididymis and fertility in the male mouse
}

\author{
R. K. Rastogi, M. Milone and G. Chieffi \\ Institute and Museum of Zoology, University of Naples, via Mezzocannone 8, 80134 Naples, \\ Italy
}

\begin{abstract}
Summary. The influence of previous sexual experience and subsequent differential housing on the epididymis and fertility index was studied for male Swiss albino cc mice. Among animals with previous sexual experience those having a high epididymal $\beta$-glucuronidase activity showed a high fertility index and vice versa. The reproductive potential of animals without previous sexual experience was reduced by housing in high-density groups and in isolation. The results show that previous sexual experience, individual housing and group volume may influence the reproductive potential of male mice.
\end{abstract}

\section{Introduction}

There have been several reviews on fertility control in the male and on the epididymis in recent years (Prasad, Singh \& Rajalakshmi, 1970; Orgebin-Crist, Danzo \& Davies, 1975; Neumann, Diallo, Hasan, Schenck \& Traore, 1976; Greep, 1976; Rastogi, 1979). The importance of several factors, e.g. nutritional, age, experience, social, physiological and hormonal, are yet to be fully understood. The role of various types of experimental factor, including manipulated socio-sexual conditions, on adult sexual behaviour has been extensively studied (see Hutchison, 1978), but as far as we are aware the influence of these factors on male fertility or on the physiology of the accessory sex organs as the end point has received little attention.

We have therefore investigated the influence of various socio-sexual conditions on the epididymis and fertility of male mice.

\section{Materials and Methods}

Male mice (Swiss albino cc strain) were isolated from their mothers and littermates at 25 days of age. Some of them were reared with sexually mature females ( 1 male: 3 females) so that when adult they were able to copulate with and impregnate the females, thus becoming experienced. The other males (inexperienced) were reared in groups of $5 /$ cage in physical isolation from females. At 45 days of age experienced and inexperienced males were placed in transparent Makrolon cages $(27 \times 42 \times 15 \mathrm{~cm})$ for 45 days and treated as follows. In Group 1 there were 5 animals/cage, i.e. a 'standard' population density. In Group 2 there were 30 animals/cage (high population density). Each animal in Group 3 was housed individually and there were no visual, olfactory or ultrasonic restrictions.

There were 5 cages in each of Groups 1 and 2 and 4 cages in Group 3. Social ranking was determined according to the criteria proposed by Brain \& Nowell $(1970,1971)$. Experimental mice were tested against relatively non-aggressive standard opponents and aggression scores were based on sniffing, biting, tail rattling and victory. Within each cage of Groups 1 and 2 one dominant and one subordinate male was identified. 
Animals were killed by ether and weighed. The epididymides were dissected out, weighed separately and homogenized in ice-cold deionized water. Proteins were determined, in the aqueous homogenate, by the method of Lowry, Rosebrough, Farr \& Randall (1951). The activity of $\beta$-glucuronidase (EC 3.2.1.31) was assayed according to the method of Lin \& Fishman (1972) and expressed as nmol phenolphthalein liberated/ $\mathrm{gg}$ protein $/ \mathrm{min}$. Values for the mice in each cage were obtained for the dominant male, the subordinate male and one randomly selected male. The sum of these values gave a value for each cage.

Additional groups of mice, treated as above, were used to determine the fertility index (see Rastogi, 1979). Each experimental male was housed for about $12 \mathrm{~h}$ with 5 oestrous females (checked by vaginal smears) and the total number of young born for each group was considered to express the fertility index as a percentage of the value obtained for experienced males before the start of experiment.

The statistical significance of differences was calculated by Student's $t$ test (Fisher, 1954).

\section{Results}

The results are shown in Text-fig. 1 .

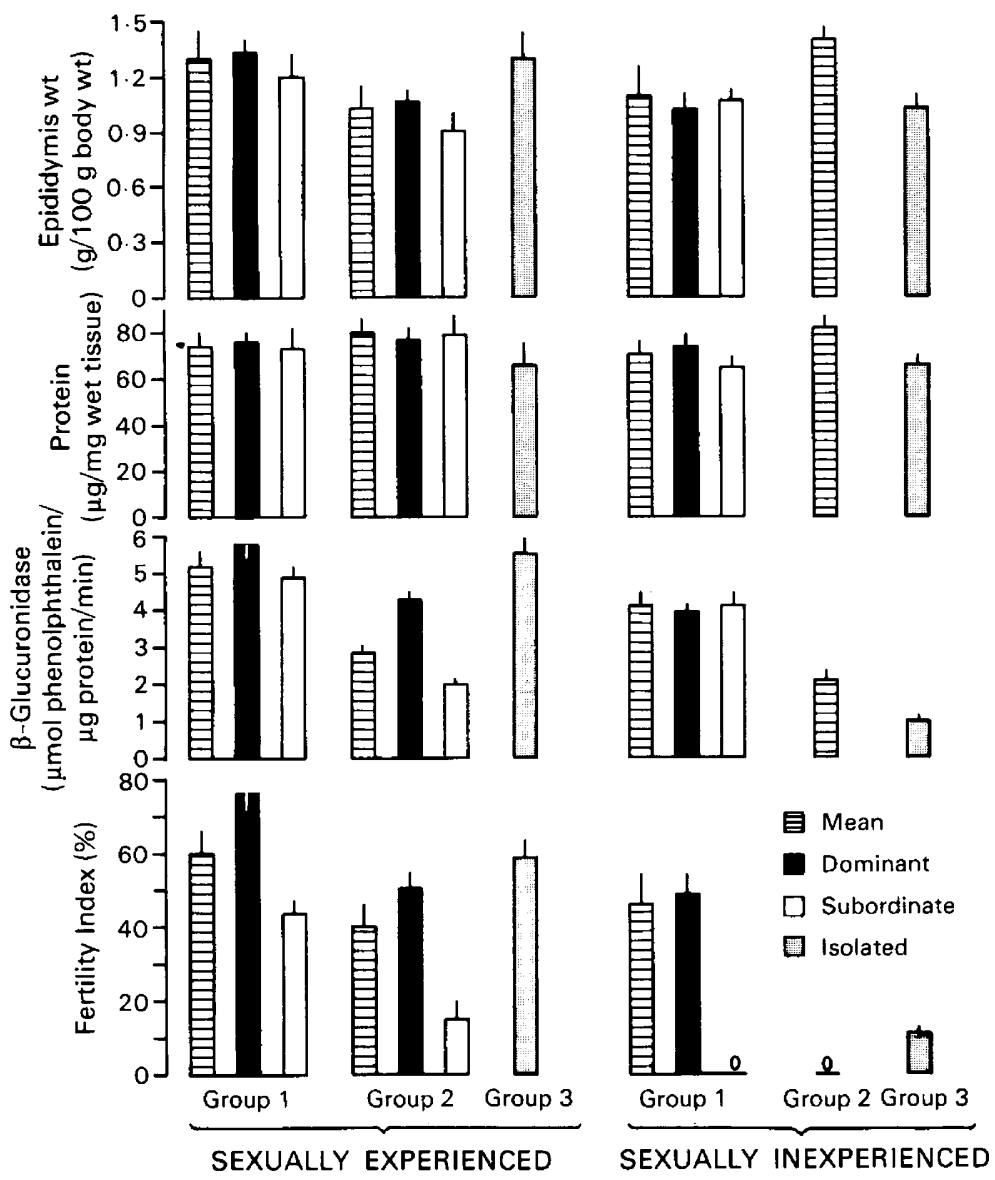

Text-fig. 1. Mean ( \pm s.e.m. for 4 (Group 2) or 5 (Groups 1 and 3) observations) values for sexually experienced and inexperienced male mice housed as 5/cage (Group 1), 30/cage (Group 2 ) or in isolation (Group 3). 
Epididymal weight. For the experienced mice social rank did not affect epididymal weight within Groups 1 and 2 but values for Group- 2 mice were all lower $(P<0.05)$ than those for Group-1 mice. Epididymal weight for the Group-3 mice was similar to that for Group-1 animals. For the inexperienced animals those in Group 2 had a significantly higher epididymal weight than did the mice in Groups 1 and $3(0.02<P<0.05)$, and this value was also higher than the equivalent value for the experienced mice $(P<0 \cdot 02)$.

Protein content. There was little difference in epididymal protein content in the groups of experienced animals, but the Group 2 value for the inexperienced animals was greater than that for Group $1(P=0.05)$ or Group $3(P<0.02)$ mice.

$\beta$-Glucuronidase activity. Experienced animals in Group 1 all showed similar enzyme activity except for a slight reduction in subordinate males as compared with dominant males $(P$ $=0.05)$. Enzyme activity was greatly decreased in Group $2(P<0.01$ for mixed value compared with Group 1). Within Group 2, subordinates had significantly lower enzyme activity than did dominant males $(P<0.01)$. The value for Group-3 mice was similar to that for Group-1 animals. In all three groups of inexperienced males the enzyme activity was significantly lower than that for the equivalent experienced groups $(0.01<P<0.05)$. The lowest enzyme activity occurred in the Group-3 inexperienced mice $(P<0.01)$.

Fertility index. Group- 2 experienced males showed decreased fertility. In Groups 1 and 2 the dominant males had a higher fertility index than did the subordinates $(P<0.01)$. Group-3 males had a fertility index significantly higher than that of Group- 2 males (mixed value: $P<$ $0.02)$ but lower than that for the dominant males in Group $1(P<0.05)$. Among the inexperienced males, all those in Group 2 were infertile. Those in Group 3 also had a very low fertility index. Within Group 1 the reasonably high fertility index was apparently all due to the fertility of the dominant males.

\section{Discussion}

Considering only the experienced males, those having a low enzyme activity showed a low fertility index and vice versa. Such a relationship, however, was not as clear cut for the inexperienced mice. The weight and protein content of the epididymis do not appear to give any indication of the reproductive potential of these animals related to their socio-sexual status. Nevertheless, $\beta$-glucuronidase activity in the mouse epididymis is known to be androgendependent (Rastogi, 1979; Rastogi, Milone, Di Meglio, Caliendo \& Chieffi, 1979), as it is in the hypothalamus of the male mouse (Milone, Rastogi, Del Sorbo, Corvino \& Caliendo, 1981). This could suggest that certain socio-sexual conditions might induce a change (increase or decrease) in the plasma androgen levels in mice which, consequently acting through the epididymal control of sperm maturation and through hypothalamic control of sexual behaviour, might regulate the fertility index of the animal.

For several mammalian species social isolation and hence sexual inexperience tends to impair adult sexual behaviour (Larsson, 1978). In several species, including the mouse, isolation decreases adrenal cortical function. Brain \& Nowell (1971) found that social isolation in male albino TT strain mice, with or without mating experience, increases pituitary-gonadal function and aggression and induces an increase in relative weights of the ventral prostate as compared with the value in grouped mice (16 mice/cage). This may indirectly mean that plasma androgen levels are elevated. We similarly found that, in isolated Swiss albino cc strain mice, epididymal weight and its $\beta$-glucuronidase activity as well as the fertility index were relatively higher than in grouped mice reared in a high population density. These values did not, however, differ significantly from the values obtained in grouped mice reared in a low population density (5 mice/cage).

It has hitherto been claimed that different cage sizes, variable pretreatment housing 
conditions, different durations of social isolation or individual housing, different age at and duration of differential housing, different age at and duration of sexual experience, and finally the strain of mice used may drastically alter the results relating to behaviour and physiology and consequently fertility (McKinney \& Pasley, 1973; Brain, 1975; Goldsmith, Brain \& Benton, 1977; Benton \& Brain, 1979). In spite of the limitations of the present study, it is evident that different social structures and conditions influence the reproductive potential of male Swiss albino cc mice.

The work was supported by the National Research Council project "Biologia della Riproduzione" and the Ministry of Education. We thank Dr D. Palmieri, Dr M. F. Caliendo and Mr R. Auriemma for their help.

\section{References}

Benton, D. \& Brain, P.F. (1979) Behavioural comparisons of isolated, dominant and subordinate mice. Behavioural Processes 4, 211-219.

Brain, P.F. (1975) What does individual housing mean to a mouse? Life Sci. 16, 187-200.

Brain, P.F. \& Nowell, N.W. (1970) Some observations on intermale aggression testing in albino mice. Commun. Behav. Biol. 4, 203-220.

Brain, P.F. \& Nowell, N.W. (1971) Isolation versus grouping effects on adrenal and gonadal function in albino mice. Gen. comp. Endocr. 16, 149-154.

Fisher, R.A. (1954) Statistical Methods for Research Workers, 12th edn. Oliver \& Boyd, London.

Goldsmith, J.F., Brain, P.F. \& Benton, D. (1977) Effects of age at differential housing and the duration of individual housing/grouping on intermale fighting behavior and adrenocortical activity in 'TO' strain mice. Aggressive Behavior 2, 307-323.

Greep, R.O. (1976) Some reflections on male reproductive biology and contraception. In Regulatory $\mathrm{Mec}$ hanisms of Male Reproductive Physiology, pp. 1-8. Eds C. H. Spilman, T. J. Lobl \& K. T. Kirton. Excerpta Medica, Amsterdam.

Hutchison, J.B. (Ed.) (1978) Biological Determinants of Sexual Behavior. John Wiley \& Sons, New York.

Larsson, K. (1978) Experimental factors in the development of sexual behavior. In Biological Determinants of Sexual Behavior, pp. 55-86. Ed. J. B. Hutchison. John Wiley \& Sons, New York.

Lin, C.-W. \& Fishman, W.H. (1972) Microsomal and lysosomal acid phosphatase isoenzymes of mouse kidney: characterization and separation. J. Histochem. Cytochem. 20, 487-498.

Lowry, O.H., Rosebrough, N.J., Farr, A.L. \& Randall,
R.J. (1951) Protein measurement with the Folin phenol reagent. J. biol. Chem. 193, 265-275.

McKinney, T.D. \& Pasley, J.N. (1973) Effects of social rank and social disruption in adult male house mice. Gen. comp. Endocr. 20, 579-583.

Milone, M., Rastogi, R.K., Del Sorbo, F., Corvino, A. \& Caliendo, M.F. (1981) Influence of cyproterone acetate on the activity of $\beta$-glucuronidase in the hypothalamus and cerebral cortex of the male mouse. Experientia (in press).

Neumann, F., Diallo, F.A., Hasan, S.H., Schenck, B. \& Traore, I. (1976) The influence of pharmaceutical compounds on male fertility. Andrologia 8, 203235.

Orgebin-Crist, M.-C., Danzo, B.J. \& Davies, J. (1975) Endocrine control of the development and maintenance of sperm fertilizing ability in the epididymis. In Handbook of Physiology, Vol. 5, pp. 319-338. Eds D. W. Hamilton \& R. O. Greep. Am. Physiol. Soc. Washington, D.C.

Prasad, M.R.N., Singh, S.P. \& Rajalakshmi, M. (1970) Fertility control in male rats by continuous release of microquantities of cyproterone acetate from subcutaneous silastic capsules. Contraception 2, $165-178$.

Rastogi, R.K. (1979) A critical appraisal of the effects of the antiandrogen, cyproterone acetate, on the epididymis in connection with fertility control in the male. J. Steroid Biochem. 11, 101-105.

Rastogi, R.K., Milone, M., Di Meglio, M., Caliendo, M.F. \& Chieffi, G. (1979) Effects of castration, $5 \alpha$-dihydrotestosterone and cyproterone acetate on enzyme activity in the mouse epididymis. $J$. Reprod. Fert. 57, 73-77. 